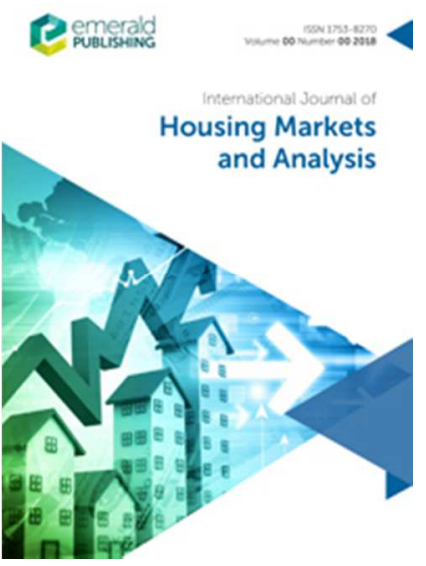

\title{
The Effect of Ground Rent and Unexpired Lease Term on Property Values in Ghana
}

\begin{tabular}{|r|l|}
\hline Journal: & International Journal of Housing Markets and Analysis \\
\hline Manuscript ID & IJHMA-05-2018-0033.R1 \\
\hline Manuscript Type: & Research Paper \\
\hline Keywords: & $\begin{array}{l}\text { Effect, Ground rent, Leasehold, Residential, Unexpired lease term, } \\
\text { Valuation }\end{array}$ \\
\hline
\end{tabular}


1

2

3

4

5

6

7

8

9

10

11

12

13

14

15

16

17

18

19

20

21

\section{List of Figures}

Figure1: Respondents' Years of Experience

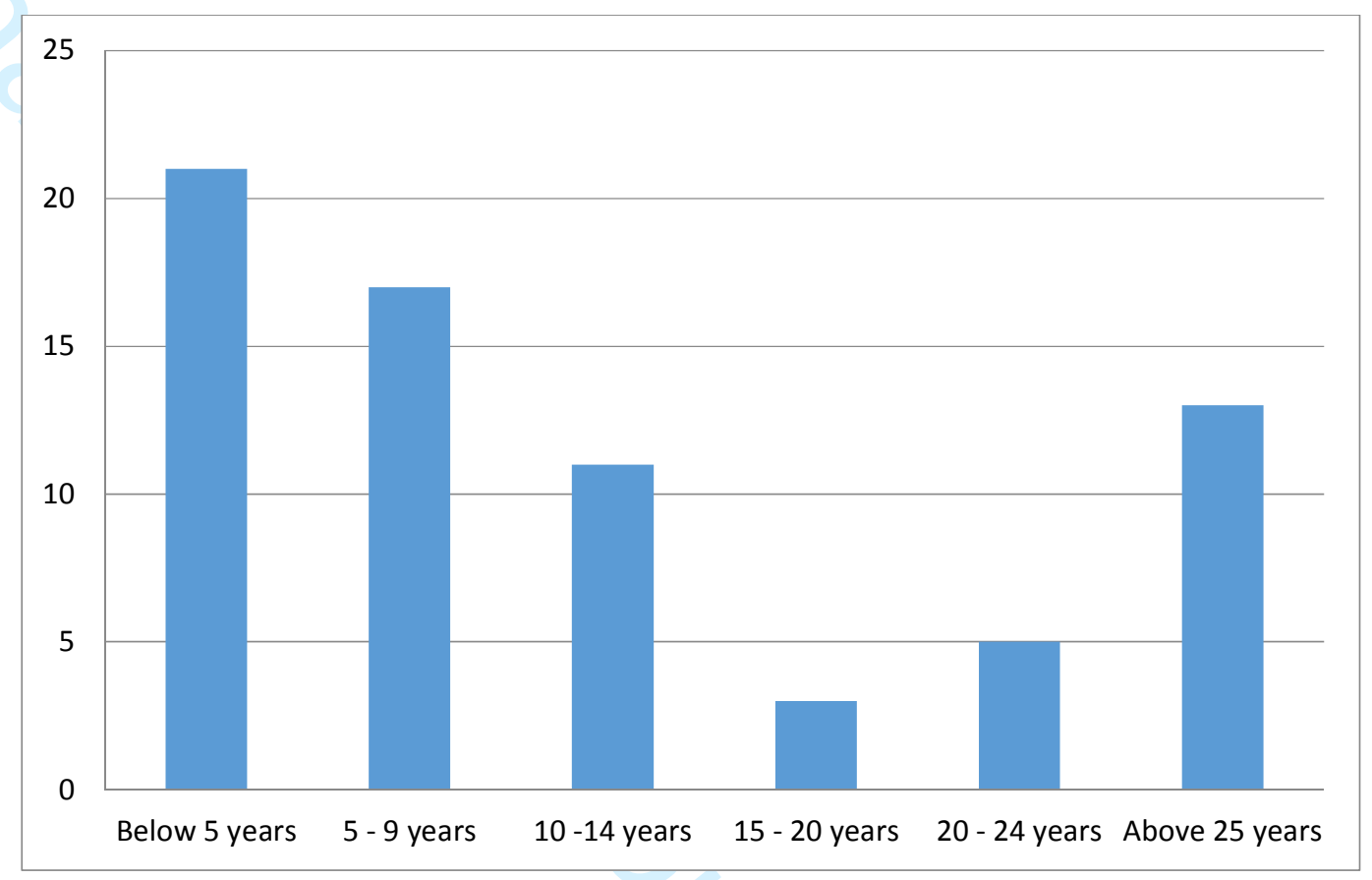

Figure 2: Nature of Professional Practice of Respondents

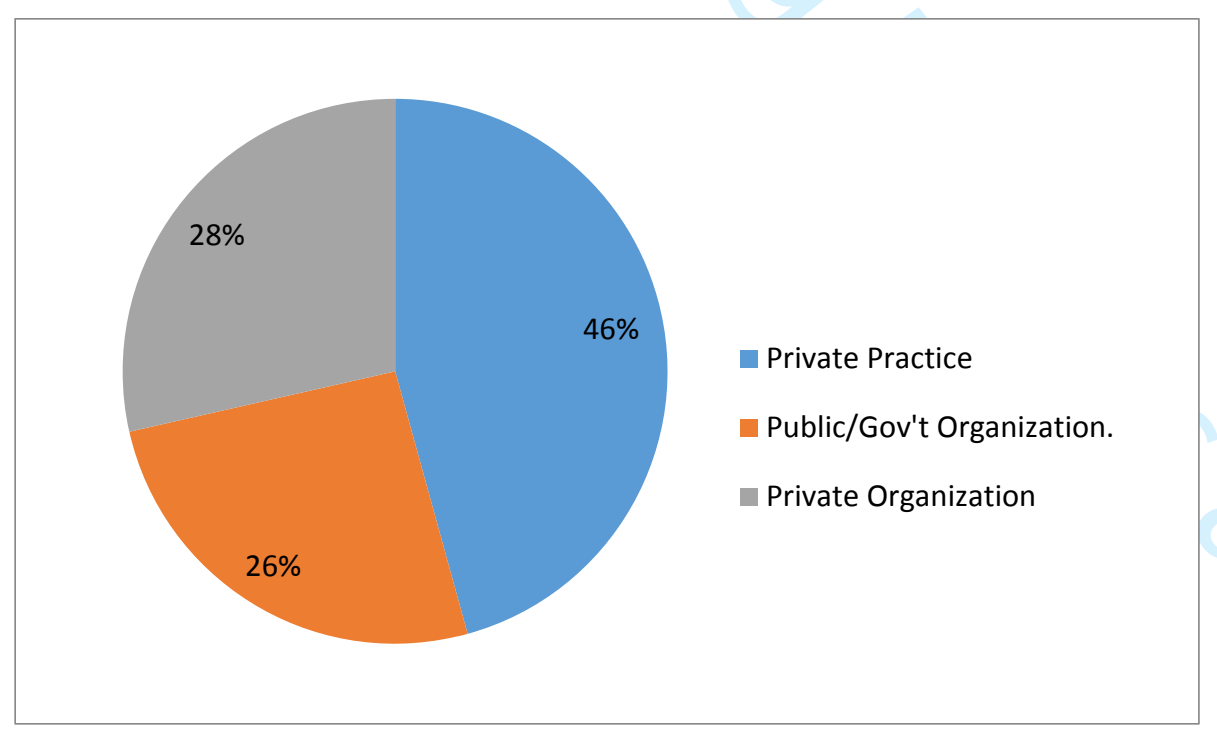




\section{List of Tables}

Table 1: Importance of Real Estate Value Attributes

Frequency

\begin{tabular}{|c|c|c|c|c|c|c|c|}
\hline Attributes & $\mathbf{N}$ & 1 & 2 & 3 & 4 & 5 & sCns \\
\hline Condition of property & 70 & 2.86 & 0.00 & 2.86 & 18.57 & 75.71 & 0.92 \\
\hline Size of land & 70 & 1.43 & 4.29 & 2.86 & 24.29 & 67.14 & 0.90 \\
\hline Neighbourhood & 70 & 2.86 & 0.00 & 7.14 & 24.29 & 65.71 & 0.89 \\
\hline Title & 70 & 2.86 & 2.86 & 10.00 & 20.00 & 64.29 & 0.87 \\
\hline Unexpired term of lease & 70 & 1.43 & 4.29 & 14.29 & 18.57 & 61.43 & 0.86 \\
\hline Availability to electricity & 70 & 2.86 & 0.00 & 7.14 & 42.86 & 47.14 & 0.86 \\
\hline Floor finish & 70 & 1.43 & 4.29 & 11.43 & 27.14 & 55.71 & 0.86 \\
\hline Size of property & 70 & 0.00 & 5.71 & 14.29 & 34.29 & 45.71 & 0.84 \\
\hline External works & 68 & 0.00 & 1.47 & 19.12 & 42.65 & 36.76 & 0.83 \\
\hline $\begin{array}{l}\text { Availability to pipe borne } \\
\text { water }\end{array}$ & 70 & 2.86 & 4.29 & 8.57 & 41.43 & 42.86 & 0.83 \\
\hline Roof & 70 & 1.43 & 2.86 & 17.14 & 35.71 & 42.86 & 0.83 \\
\hline Doors & 70 & 1.43 & 2.86 & 17.14 & 38.57 & 40.00 & 0.82 \\
\hline Fixtures and Fittings & 70 & 1.43 & 1.43 & 20.00 & 38.57 & 38.57 & 0.82 \\
\hline Ceiling & 70 & 1.43 & 2.86 & 18.57 & 37.14 & 40.00 & 0.82 \\
\hline Windows & 69 & 1.45 & 2.90 & 18.84 & 37.68 & 39.13 & 0.82 \\
\hline Number of rooms & 69 & 1.45 & 7.25 & 15.94 & 30.43 & 44.93 & 0.81 \\
\hline Walls & 70 & 1.43 & 4.29 & 20.00 & 34.29 & 40.00 & 0.81 \\
\hline Registration status & 70 & 1.43 & 11.43 & 17.14 & 27.14 & 42.86 & 0.78 \\
\hline Age of property & 70 & 2.86 & 5.71 & 28.57 & 27.14 & 35.71 & 0.76 \\
\hline Proximity to highway & 69 & $4 \cdot 35$ & 5.80 & 31.88 & 40.58 & $17 \cdot 39$ & 0.71 \\
\hline Proximity to other social & 68 & 1.47 & 8.82 & 36.76 & 41.18 & 11.76 & 0.69 \\
\hline Planning scheme & 70 & 4.29 & 11.43 & 31.43 & 32.86 & 20.00 & 0.69 \\
\hline Access to $C B D$ & 70 & 4.29 & 12.86 & 35.71 & 28.57 & 18.57 & 0.67 \\
\hline Type of land & 66 & 9.09 & 16.67 & 19.70 & 30.30 & 24.24 & 0.66 \\
\hline Proximity to shops & 70 & 2.86 & 11.43 & 41.43 & 37.14 & 7.14 & 0.65 \\
\hline Availability to telephone & 69 & 7.25 & 13.04 & 28.99 & 36.23 & 14.49 & 0.65 \\
\hline Building permit & 69 & 8.70 & 13.04 & 33.33 & 28.99 & 15.94 & 0.63 \\
\hline Proximity to airport & 68 & 7.35 & 16.18 & 33.82 & 29.41 & 13.24 & 0.62 \\
\hline Proximity to schools & 69 & 4.35 & 20.29 & 42.03 & 26.09 & 7.25 & 0.59 \\
\hline Orientation to rooms & 68 & 11.76 & 22.06 & 38.24 & 22.06 & 5.88 & 0.53 \\
\hline Ground rent & 68 & 17.65 & 30.88 & 26.47 & 19.12 & 5.88 & 0.47 \\
\hline Access to church & 69 & 15.94 & 43.48 & 24.64 & 15.94 & 0.00 & 0.41 \\
\hline
\end{tabular}

This table reports the level of consensus on the importance of real estate value attributes to the value of residential properties. 
Table 2: Extent of Importance of Real Estate Value Attributes by Years of Experience

\begin{tabular}{lccccccc}
\hline Attribute & $\mathbf{N}$ & $\mathbf{1}$ & $\mathbf{2}$ & $\mathbf{3}$ & $\mathbf{4}$ & $\mathbf{5}$ & sCns \\
\hline Proximity to airport & & & & & & & \\
Below 5 years & 20 & 5.00 & 10.00 & 30.00 & 40.00 & 15.00 & 0.68 \\
Between 5 and 15 years & 28 & 10.71 & 17.86 & 32.14 & 21.43 & 17.86 & 0.60 \\
Above 15 years & 20 & 5.00 & 20.00 & 40.00 & 30.00 & 5.00 & 0.59 \\
Unexpired Term & & & & & & & \\
Below 5 years & 21 & 0.00 & 4.76 & 14.29 & 9.52 & 71.43 & 0.89 \\
Between 5 and 15 years & 28 & 3.57 & 0.00 & 17.86 & 28.57 & 50.00 & 0.84 \\
Above 15 years & 21 & 0.00 & 9.52 & 9.52 & 14.29 & 66.67 & 0.87 \\
Ground Rent & & & & & & & \\
Below 5 years & 19 & 0.00 & 21.05 & 31.58 & 21.05 & 26.32 & 0.69 \\
Between 5 and 15 years & 28 & 17.86 & 35.71 & 28.57 & 7.14 & 10.71 & 0.45 \\
Above 15 years & 21 & 14.29 & 23.81 & 28.57 & 28.57 & 4.76 & 0.52 \\
\hline
\end{tabular}

This table reports the level of consensus on the importance of proximity to airport, unexpired lease term and ground rent to the value of residential properties disaggregated by the level of professional experience of the respondents. 
Table 3: Extent of Importance of Real Estate Value Attributes by Nature of Professional Practice

\begin{tabular}{|c|c|c|c|c|c|c|c|}
\hline Attribute & $\mathbf{N}$ & 1 & 2 & 3 & 4 & 5 & sCns \\
\hline \multicolumn{8}{|l|}{ Proximity to airport } \\
\hline Private practice & 30 & $3 \cdot 33$ & 13.33 & 33.33 & 40.00 & 10.00 & 0.66 \\
\hline Public/Gov't Inst & 18 & 11.11 & 27.78 & 38.89 & 22.22 & 0.00 & 0.50 \\
\hline Private Organization & 19 & 10.53 & 5.26 & 31.58 & 21.05 & 31.58 & 0.69 \\
\hline \multicolumn{8}{|l|}{ Unexpired Term } \\
\hline Private practice & 31 & 0.00 & 6.45 & 22.58 & 9.68 & 61.29 & 0.84 \\
\hline Public/Gov't Inst & 18 & 0.00 & 5.56 & 16.67 & 16.67 & 61.11 & 0.86 \\
\hline Private Organization & 20 & 5.00 & 0.00 & 0.00 & 35.00 & 60.00 & 0.88 \\
\hline \multicolumn{8}{|l|}{ Ground Rent } \\
\hline Private practice & 31 & 22.58 & 32.26 & 25.81 & 16.13 & 3.23 & 0.42 \\
\hline Public/Gov't Inst & 17 & 11.76 & 23.53 & 29.41 & 23.53 & 11.76 & 0.56 \\
\hline Private Organization & 19 & 15.79 & 36.84 & 26.32 & 15.79 & 5.26 & 0.45 \\
\hline
\end{tabular}


Table 4: OLS Regression relating opinions of value to Unexpired Lease Term and Ground Rent

\begin{tabular}{|c|c|c|c|c|c|c|c|c|c|}
\hline 20 & \multicolumn{3}{|c|}{ Model 1} & \multicolumn{3}{|c|}{ Model 2} & \multicolumn{3}{|c|}{ Model 3} \\
\hline & Coefficient & t-stat & $\begin{array}{l}\mathrm{p} \text { - } \\
\text { value }\end{array}$ & Coefficient & t-stat & $\begin{array}{l}\mathrm{p}- \\
\text { value }\end{array}$ & Coefficient & t-stat & p-value \\
\hline Constant & $13.98 * * *$ & 24.45 & 0.00 & $13.76 * * *$ & 34.66 & 0.00 & $14.04 * * *$ & 24.75 & 0.00 \\
\hline Proximity to Airport & $0.18 *$ & 1.82 & 0.07 & $0.19^{*}$ & 1.95 & 0.06 & $0.19 *$ & 1.95 & 0.06 \\
\hline Unexpired Term & $-0.19 *$ & -1.71 & 0.09 & & & & -0.09 & -0.72 & 0.47 \\
\hline Ground Rent & & & & $-0.23^{* *}$ & -2.51 & 0.02 & $-0.20 *$ & -1.92 & 0.06 \\
\hline Adj. $R^{2}$ & 0.06 & & & 0.11 & & & 0.11 & & \\
\hline Observations & 65 & & & 65 & & & 65 & & \\
\hline F-stat & $3.08 *$ & 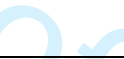 & & $4.84^{* *}$ & & & $3.40 * *$ & & \\
\hline
\end{tabular}

This table reports the OLS regression relating valuers' opinion of values to their views on the importance of unexpired lease terms, ground rent and proximity to airport in determining the values of residential properties. ${ }^{* *}, * *$ and $*$ indicate statistical significance based on a two-tailed test at the $1 \%$, $5 \%$ and $10 \%$ levels respectively. 
Table 5: Quantile Regression Relating Opinion of Value to Unexpired Term and Ground Rent

\begin{tabular}{|c|c|c|c|c|c|c|c|c|c|}
\hline 30 & 0.1 & 0.2 & 0.3 & 0.4 & 0.5 & 0.6 & 0.7 & 0.8 & 0.9 \\
\hline \multicolumn{10}{|c|}{ PANEL A: Quantile Regression Relating Opinions of Value to Proximity to Airport and Unexpired Term } \\
\hline Constant & $\begin{array}{r}11.89 \\
(0.00)\end{array}$ & $\begin{array}{r}12.64 \\
(0.00)\end{array}$ & $\begin{array}{r}13.89 \\
(0.00)\end{array}$ & $\begin{array}{r}14.53 \\
(0.00)\end{array}$ & $\begin{array}{r}14.89 \\
(0.00)\end{array}$ & $\begin{array}{r}14.49 \\
(0.00)\end{array}$ & $\begin{array}{r}15.09 \\
(0.00)\end{array}$ & $\begin{array}{r}14.76 \\
(0.00)\end{array}$ & $\begin{array}{r}15.09 \\
(0.00)\end{array}$ \\
\hline Proximity to Airport & $\begin{array}{r}0.56 \\
(0.02)\end{array}$ & $\begin{array}{r}0.40 \\
(0.06)\end{array}$ & $\begin{array}{r}0.17 \\
(0.09)\end{array}$ & $\begin{array}{r}0.10 \\
(0.43)\end{array}$ & $\begin{array}{r}0.05 \\
(0.67)\end{array}$ & $\begin{array}{r}0.17 \\
(0.15)\end{array}$ & $\begin{array}{r}0.10 \\
(0.25)\end{array}$ & $\begin{array}{r}0.15 \\
(0.08)\end{array}$ & $\begin{array}{r}0.05 \\
(0.75)\end{array}$ \\
\hline Unexpired Term & $\begin{array}{r}-0.26 \\
(0.38)\end{array}$ & $\begin{array}{r}-0.19 \\
(0.51)\end{array}$ & $\begin{array}{r}-0.21 \\
(0.13)\end{array}$ & $\begin{array}{r}-0.26 \\
(0.08)\end{array}$ & $\begin{array}{r}-0.28 \\
(0.04)\end{array}$ & $\begin{array}{r}-0.21 \\
(0.11)\end{array}$ & $\begin{array}{r}-0.27 \\
(0.00)\end{array}$ & $\begin{array}{r}-0.19 \\
(0.04)\end{array}$ & $\begin{array}{r}-0.15 \\
(0.29)\end{array}$ \\
\hline $\mathrm{R}^{2}$ & 0.07 & 0.06 & 0.06 & 0.07 & 0.07 & 0.07 & 0.08 & 0.09 & 0.04 \\
\hline
\end{tabular}

PANEL B: Quantile Regression Relating Opinions of Value to Proximity to Airport and Ground Rent

\begin{tabular}{lrrrrrrrrr} 
Constant & 13.18 & 12.68 & 13.38 & 13.42 & 13.91 & 13.87 & 14.33 & 14.27 & 14.84 \\
& $(0.00)$ & $(0.00)$ & $(0.00)$ & $(0.00)$ & $(0.00)$ & $(0.00)$ & $(0.00)$ & $(0.00)$ & $(0.00)$ \\
Proximity to Airport & 0.20 & 0.29 & 0.16 & 0.18 & 0.14 & 0.24 & 0.13 & 0.19 & 0.07 \\
& $(0.34)$ & $(0.22)$ & $(0.26)$ & $(0.18)$ & $(0.30)$ & $(0.02)$ & $(0.19)$ & $(0.09)$ & $(0.39)$ \\
Ground Rent & -0.46 & -0.25 & -0.15 & -0.12 & -0.19 & -0.21 & -0.16 & -0.16 & -0.16 \\
& $(0.04)$ & $(0.39)$ & $(0.35)$ & $(0.41)$ & $(0.15)$ & $(0.03)$ & $(0.08)$ & $(0.07)$ & $(0.01)$ \\
$\mathrm{R}^{2}$ & 0.17 & 0.10 & 0.07 & 0.06 & 0.05 & 0.05 & 0.06 & 0.06 & 0.05 \\
\hline
\end{tabular}

This table reports the results of the quantile regression relating valuers' opinion of values to their views on the importance of unexpired lease terms, ground rent and proximity to airport at different quantiles. P-values are in parentheses. 


\title{
The Effect of Ground Rent and Unexpired Lease Term on Property Values in Ghana
}

\author{
Abstract \\ Purpose: \\ Although several factors influence property value \\ determination depending on the market, relevant \\ studies in Sub-Saharan Africa (SSA) often fail to analyse \\ the impact of factors, such as unexpired term of \\ leasehold interest and ground rent, which are also \\ germane to market transactions and value \\ determination. This study examines the effect of \\ unexpired term of leasehold interests and ground rent \\ on the valuation of residential properties in Ghana.
}

Design/Methodology/Approach: A questionnaire instrument was used to collect the views of a sample of professional real estate valuers on the relevance of these and other factors that affect value. In addition, the valuers were tasked to value a residential property located in Accra, Ghana. OLS and Quantile regression models were thereafter used to analyse the data to determine the effect of the subject variables on value.

Findings:

The study finds a significant relationship between valuers' views on the relevance of unexpired term of leasehold interest and the value placed on residential properties. Further, the respondents who viewed ground rent as an important factor in estimating values placed significantly lower values than those who viewed it as less important.

Research Implications:

The findings suggest that the respondents may have split opinion on the existing anecdotal evidence that 
market participants ignore the unexpired term of leasehold interest, an issue that should be settled in theory. The findings also highlight the diversity of opinion on some of the fundamental factors that affect value and the need to build consensus to prevent excessive variation in value estimates among valuers.

Originality:
The study makes a significant contribution in terms of extending the existing literature by analysing the impact of unexpired term of leasehold interests and ground rent on residential property values based on empirical data, issue(s) which have often been ignored by existing studies. Findings from the study also provide insights into additional possible causes of valuation errors in Ghana and SSA, which are useful for policy formulation and practice.

Keywords: Effect, ground rent, leasehold, residential, unexpired lease term, valuation

\section{Introduction}

Current evidence suggests that Africa's diverse real estate markets continue to grow and develop (Viruly and Hopkins, 2014; Baffour Awuah and Gyamfi-Yeboah, 2017). These markets are attracting growing interest from several investor types, such as hedge and sovereign wealth funds across the various real estate sectors. The growing interest is partly because of enabling conditions including improvement in product quality, high yields and improving market transparency. This implies that property markets across the continent are on the path to maturity although performance across constituent economies is uneven.

As real estate markets mature and transparency improves, market stakeholders particularly property owners, tenants, communities, investors and financiers are also becoming more 
sophisticated. Thus, they are becoming wearier of and paying special attention to real estate imperatives. These include real estate transaction cost; real estate interest; leasehold terms and conditions; neighbourhood conditions; and particularly factors that affect property values. Whilst several studies (Palmquist, 1994; Cheshire and Sheppard, 2002, 2004; Sirmans et al., 2005a; del Saz-Salazar and Garcia-Menéndez, Glaeser and Ward, 2009; Zopi et al., 2015) have examined the traditional factors that affect the values of residential properties, the effect of factors such as ground rents and unexpired lease terms have largely been unexplored. In addition, the small strand of studies in SSA that examine the impact of a range of real estate attributes on property values, such as Asabere (1981), Megbolugbe (1989), Arimah (1992), Anim-Odame et al. (2006), Owusu-Ansah (2012) and Adekoge (2014) have not adequately examined peculiar factors that influence values in local markets.

This study investigates the extent of the impact of factors that influence residential property values in Ghana with emphasis on unexpired term of leasehold interests and ground rents. Real estate valuation principles hold that reduction in the term of a leasehold (terminable interest) interest particularly below 50 years results in value diminution (Shapiro and Mackmin, 2013). The records at Ghana's Lands Commission' show that most of the leases granted over properties especially those in prime areas in Accra, the country's capital city, such as Airport West, Cantonments and Ridge residential areas in the 1950 s and 1960 s are fast expiring. The majority of these leases have less than 15 years to run. Yet anecdotal evidence indicates that such unexpired terms hardly have impact on the amounts paid for these leasehold properties. Although this phenomenon could pose challenges to market and investment decision-making, the issue continues to beg empirical investigation.

An enduring feature of lease agreements is the payment of rent. In the case of a ground lease, the ground rent represents an outgoing for the owner of the leasehold interest. The impact the ground rent has on the value of a leasehold property should depend on whether it constitutes a small or large proportion of land value. Conventionally, ground rents tend to constitute a minimal proportion of land or property value (Shapiro and Mackmin, 2013;

\footnotetext{
${ }^{1}$ The main public land administration and management institution in the country with the responsibility to manage public lands, land surveying and mapping, valuation and registration among other things.
} 
Baffour Awuah et al., 2014b). For peppercorn ground rent, the amount could even be very little because it is just a token amount paid to atone tenancy (McIntosh and Sykes, 1985; the Guardian, 2017). This means that, all things being equal, ground rent should theoretically have little or no impact on property values. In recent times, however, due largely to the increasing commodification of land, rising land values and the wide recognition of the economic significance of land especially in urban areas, such as Accra, lessors are beginning to charge full economic land rent. Recent anecdotal evidence shows that the Lands Commission, which has the responsibility for the management of public lands in Ghana, is beginning to charge the annual equivalent of the capital values of some of its land grants under leasehold arrangements. Thus, it is unclear the extent to which ground rent affects the value of leasehold properties given the recent developments including how this is influencing valuation practice in the country.

Using a questionnaire instrument on a sample of professional real estate valuers, the study finds that, the views of valuers on the relevance of unexpired term of leasehold interest affect the values placed on residential properties. This suggests that the anecdotal evidence that market participants ignore the unexpired term of a leasehold interest may have split opinion on an issue that is settled in theory. The study also finds that the respondents who viewed ground rent as an important factor in estimating values placed significantly lower values than those who viewed it as less important. The rest of the paper is organised as follows: the next section reviews the relevant literature. The data and methodology, results and the conclusion follow this.

\section{Literature Review and Conceptual Framework}

Like most commodities, neo-classical economic theory postulates that the price of a real estate in pure price operated markets is determined through the interaction of its demand and supply conditions (Fehriback et al., 1993; Lockwood and Rutherford, 1996; Griffiths and Walls, 2011; Sloman et al., 2012). Unlike many other commodities, real estate is heterogeneous in nature comprising several attributes (Dobson and Goddard, 1992; Fehriback et al., 1993; O’Sullivan, 2009; McDonald and McMillen, 2011; Jowsey, 2011). 
Consequently, a combination of demands for these attributes embedded in a real estate at a given supply level in pure price operated markets determine the price and ultimately the value of a real estate. Studies including those that employ both the hedonic price and Ordinary Least Square (OLS) Regression analytical models (Cheshire and Sheppard, 2002, 2004; Sirmans et al., 2005a; del Saz-Salazar and Garcia-Menéndez, 2005; Ihlanfeldt, 2007, 2009; Glaeser and Ward, 2009; Zopi et al., 2015) enhance understanding that real estate is a heterogeneous and composite commodity. Thus, it comprises a bundle of attributes. Accordingly, the demand for these attributes and the quantum of them embedded in real estate determine its value.

The real estate literature particularly those relating to the developed world identifies several of these attributes. In fact, some studies (Palmquist, 1994; Sirmans et al., 2005a; Orefice, 2007; Medda, 2012; Zopi et al., 2015) have classified these attributes or factors into broad categories. However, the categorisation by Sirmans et al. (2005a) is worthy of note given its comprehensive nature particularly in relation to the litany of the attributes that were identified by the study. The study reviewed 125 studies and classified house price attributes into eight main groups. These groups are construction and structure; house internal features; house external amenities; environmental - natural; environmental neighbourhood and location; environmental - public service; marketing - occupancy and selling factors; and financing issues.

The study identified as many as 360 attributes and noted that they could be more depending particularly on location specific market dynamics. Although Sirmans et al. (2005a) is a USAbased study, most of the studies before and after the study especially across the developed world on the impact of attributes of property on real estate values have used most of these attributes. Kryvobokov (2007) also investigated the most important location attributes, which work in market conditions within different countries. The study noted that the attributes used in developed, transition and developing economies often demonstrate the level of development in a particular country with developing countries often employing few attributes perhaps due to data challenges. However, the study found that the most used 
attributes are CBD accessibility; demographic characteristics; accessibility to water bodies, such as lakes; and accessibility to green areas like golf courses. The remainder is income level and prestige of a particular population; accessibility to commercial objects and their characteristics; accessibility to roads and their characteristics; planning and urban development characteristics; nuisance proximity; educational level of a population; and crime level.

Comparatively fewer studies carried-out in SSA, such as Asabere (1981), Megbolugbe (1989), Arimah (1992), Anim-Odame et al. (2006), Owusu-Ansah (2012), Adekoge (2014), and Abidoye and Chan $(2016,2017)$ have followed those of the developed world studies. In particular, these studies focus on the impact of the structural, neighbourhood and locational characteristics of real estate on its value. However, the impact of proximity to airport and other factors, such as unexpired term of a leasehold interest, building permit, encumbrances, stamp duty payment and real estate transactions in foreign currencies, which are also germane to the region's real estate markets and value determination have hardly been examined. This corroborates Kryvobokov (2007) findings that relevant studies comparatively analyse the impact of few real estate attributes on property values in developing countries.

\section{Impact of Real Estate Attributes}

There is now a consensus within the literature that real estate attributes have impact on real estate value. However, the growing body of real estate literature shows that the extent of impact of these attributes on real estate value, in particular, across different markets is not even. Sirmans et al. (2005a) identified 20 most used real estate attributes in a hedonic price models. These included lot size, age, square foot, number of rooms and bedrooms, garage space, availability of swimming pool and distance to amenities. Age was the most employed attribute with 78 appearances, but in 63 instances, its impact was negative whilst in seven and eight times, it had positive and no significant impact respectively. The impact of square foot, garage spaces and lot size was positive compared, for instance, to time on market, which had mostly negative impact or no significant impact. 
Sirmans et al. (2005b) carried-out a further study using the hedonic price model based on Meta regression analysis technique to determine the impact of nine prominent attributes in the earlier study on house prices. These attributes were square foot, lot size, age, bedrooms, bathrooms, garage, swimming pool, fireplace and air-conditioning. The study concluded that overall, the impact of these attributes on house prices had not changed much except for age, which was affected by time and the impact was negative. Ihlanfeldt (2007) based on data from 100 cities in Florida, found that greater land use regulation restrictiveness leads to increases in house prices and decreases land prices. Ihlanfeldt (2009) based on attributes, such as distance to CBD, and amenities and density, further found that land use planning makes a significant positive impact on house values. In addition, Glaeser and Ward (2009) found that all things being equal minimum lot size could increase house values in Greater Boston and that land use regulation has significant positive impact on house prices.

Studies such as Cheshire and Sheppard $(2002,2004)$ in the UK have demonstrated that factors like density, access to infrastructure and services, and neighbourhood characteristics have a significant positive impact on property values. Further, Zoppi et al. (2015) in the city of Cagliari, Italy found that smaller house size, as well as position and topographical qualities of houses were the main drivers of increases in house values. The study examined these factors together with other factors including characteristics of housing units, such as finished interior area; demographic features of neighbourhood like density and permanent residents; plan-related characteristics of neighbourhood; and artificial land cover of neighbourhood where a house is located. In Spain, Del Saz-Salazar and Garcia-Menéndez (2005) found that location in terms of distance to a highway, CBD and a province have significant impact on property values although their unit of analysis was an industrial land.

Studies on the impact of real estate attributes on residential property values in SSA show some variations in impact among real estate attributes depending on the model employed and the number of attributes used. In broad terms, however, the attributes with significant impacts have often been planning, neighbourhood and accessibility to infrastructure and 
amenities. For instance, based on a review of relevant studies Abidoye and Chan (2016) identified 20 attributes, which have significant impact on property values in Lagos, Nigeria. These include: accessibility to shopping mall, school, place of work, public transport facility, CBD, highway; availability of electricity, pipe-borne water, waste disposal system, security; and age, size of property, state of repair, number of bedrooms and other building characteristics. Similar such factors have previously been found to have positive impact on property values in Ghana. These factors include availability of electricity, pipe-borne water, tarred roads and title (Asabere, 1981; Anim-Odame, 2006; Owusu-Ansah, 2012; Baffour Awuah et al., 2014a); access to CBD and highway (Asabere, 1981; Anim-Odame, 2006; OwusuAnsah, 2012); and number of bedrooms, size and condition of property (Anim-Odame, 2006; Owusu-Ansah, 2012). However, as previously mentioned, studies on the impact of unexpired term of leasehold properties and ground rents have remained marginal.

\section{The Evolution of Leasehold Estates in SSA}

Leasing in real estate is a contractual arrangement to grant interest in land and real estate for a pre-defined length of time (Hicks, 1972; Bracke et al., 2014). Apart from providing an avenue for an alternative form of ownership outside of ownership in perpetuity, it is also a useful land and property management mechanism (Fry and Mark, 1984; Hong, 1995). It is a form of land and property holding, which has a long historical antecedent especially in England and continental Europe (Hicks, 1972; Fry and Mark, 1984). Countries, such as the UK, USA, Singapore, Hong Kong, Australia and China use leasing to create alternative form of land and property ownership (Bracke et al., 2014; Emerge Capital, 2014). This contractual arrangement occurs between the grantor of a leasehold interest usually a freeholder who owns the land or real estate in perpetuity or someone who has superior interest in the land known as lessor or landlord (property owner) and the proposed owner of the leasehold interest often referred to as a lessee or tenant.

As a form of ownership, leasehold interests confers on its owner certain rights and privileges. These include the right to use the land and real estate within the framework of a country's law, the right to sell or mortgage the leasehold interest, right to possession of the 
land and the real estate, and right to quite enjoyment (Hong, 1995; Blackledge, 2017). In consideration of these rights and privileges, the lessee is supposed to perform certain responsibilities including the recognition of his/her lessor, payment of rent and certain taxes, such as property tax in certain jurisdictions and not undertaking improvements, which have not been agreed upon with the lessor (Hicks, 1972; Fry and Mark, 1984; Blackledge, 2017). Further, upon expiration of the lease, a lessee may have to renegotiate for lease extension or renewal. Otherwise, the property or land together with the improvement will revert to the lessee (Blackledge, 2017). This may be dependent on the type of lease, and the relevant legal regime operating in a particular country. Under market conditions, the rent paid is usually market rent. However, a lessee may be entitled to a reduced rent upon payment of an initial premium, which is a lump sum. A rent reduction may also occur where an existing leasehold interest is surrendered for a lease extension (Blackledge, 2017; Baum et. al., 2018).

Leases may come in various forms and types. Miller and Upton (1976), for example, identified lease types, such as full-recourse leases, leveraged leases, operating leases, financial leases, net leases, and short-term and long-term leases. There is also occupational, and ground or building lease (Blackledge, 2017). Occupational lease entails the leasing of land together with its improvements. Rents paid under occupational lease are called occupational rents. Conversely, Ground or building lease occurs where a bare land - green or brown field is given out on a lease. The rent payable under a ground or building lease is called ground rent. Fundamentally, a purchase or holding of land and real estate is considered as an investment (Barlowe, 1990). From the investment standpoint, therefore, the reason for granting leases is to obtain rental income (Miller and Upton; Benjamin, 1995; Emerge Capital, 2014). Apart from rental income, several reasons underlie the grant of leases. Leases especially public land leasing is a tool for promoting inter-generational custodianship of land (Emerge Capital, 2014). This is very useful in terms of intergenerational equity, which constitutes a core component of sustainable development. Further, public land leasing are used to manage urban growth, promote industrial development and subsidize affordable housing, as well as raise public funds (Hong, 1995). These are usually achieved through the terms and conditions inserted in leasehold 
agreements, which provide a mix of incentives and disincentives for the objectives to be realised.

Although some form of land markets existed in SSA particularly in West Africa, which had a rich urban tradition, European colonialists introduced formal land markets and leasing in the region mostly at the turn of the nineteenth century (Baffour Awuah, 2013). This is traceable to the common foundation discharged by the Berlin Conference of 1884-1845, which agreed the partition of Africa among European powers (Okoth-Ogendo, 2000). Following the partition and colonisation of the continent, the European colonialists supplanted African indigenous land tenure systems with land administration and planning policies that existed in Europe (Home, 2012; Baffour Awuah, 2013). Although these policies were not uniform across countries on the continent, a common outcome from them was the permission of land commodification in Africa and in some instances the vesting of entire land ownership in colonial governments (Okoth-Ogendo, 2000; Hammond and Antwi, 2010). A prominent characteristic of the new regime was to enable the colonial governments to control all land transactions and become owners of so called "unoccupied and ownerless" lands particularly in East Africa to make generous land grants to European companies, which were involved in large scale commercial plantations and mining activities (Okoth-Ogendo, 2000; Home, 2012). However, due to the rich urban tradition in West Africa, the colonial governments' land acquisition practices were mainly limited to compulsory purchase of land for the development of public projects.

The European land administration and planning policies parachuted into Africa culminated in the institutionalisation of rights, interests and instruments, such as freehold, leasehold, subleasehold, license, and certificates of appropriation and use. For example, the British Colonial Government promulgated Land Legislation 1876-1897 in Gold Coast now Ghana. Part of this legislation conferred on the colonial government compulsory purchase powers, which were exercised to acquire lands for public projects. The legislation extinguished all interests and rights over lands acquired and vested the freehold interests in the government. The British Colonial Government also used the legislation to acquire land for 
residential developments. The legislation on compulsory acquisition has since changed first from the colonial legislation to 1960 State Property and Contracts Act (CA6) and thereafter the State Lands Act (1962) (Act 125) with its amendments. This compulsory acquisition of land for residential purpose allowed particularly public servants to access housing or land for housing development. Upon acquisition, the lands were put in the pool of lands already being managed by the Lands Department now the Lands Commission, which was the country's institution charged with the responsibility for managing public lands. The Lands Department in collaboration with relevant public agencies, such as the Department of Town and Country Planning then prepared sub-division plans over the lands, surveyed and then provided infrastructure such as roads for them. Thereafter, the Department made allocations of the lands based on examination of applications received and granted 99-year ground or building leases over them to beneficiaries particularly for residential lands. Records at the Lands Commission show that allottees of public residential lands paid comparatively small sums of money towards surveying and pillaring of relevant plots of land, but they were not made to pay premiums. Accordingly, payment of premiums was not factored in the analysis. Further, the ground rents charged under the said leases were small. Indeed, the leases engrossed during that period and until the 1990 s were without rent review clauses. However, upon expiration of the leases the lessees were supposed to freely yield the land together with the improvements to government, the lessor. These colonial practices have largely remained up to date except that the Lands Commission charges premiums for lease extension and has introduced rent review clauses in its leases. What was also clear is that lessees were and are still mostly entitled to lease renewals or extension. However, such extensions come at a cost.

\section{Impact of Unexpired Lease Term and Ground Rent}

Although not like other physical attributes of properties as discussed in the previous sections, unexpired term of a leasehold interest and ground rent have effect on the value of leasehold residential properties. In the case of unexpired term of leasehold interest, for 
example, Bracke et al. (2014) in the city of London, the UK examined the relationship between lease length and sales prices of houses/flats based on house/flat prices from 1987 to 1992. The study among other findings noted that the value of long leaseholds of different lengths cannot be statistically different from the value of other long leaseholds of a different length. The study also established that unexpired term of a leasehold interest has a significant effect on sale price. It was further found that sale prices of leasehold interests broadly reflect predictions relating to the deterioration of prices of wasting assets drawn from finance theory. This partly seems to corroborate the findings from Giglio et al. (2014), which used leasehold and freehold properties in the UK and Singapore to assess the discount rates applied to benefits that occur 100 or more years in the future, and found a very low long-run discount rates of about $2.5 \%$.

Indeed, a reduction in the term of a leasehold interest in real estate particularly below 50 years culminates in value reduction (Shapiro and Mackmin, 2013; Blackledge, 2017; Baum et. al., 2018). Traditionally, valuation of a leasehold interest in real estate, often referred to as a wasting asset is by the formulae:

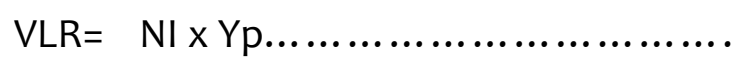

(1)

Where:

$V L R=$ Value of a Leasehold interest in Real Estate

$\mathrm{Nl}=$ Net Income (Net Rental Income/profit rent) per annum

$Y p=$ Years Purchase for the term / unexpired term of the lease - the case of single rate is used

The formulae for assessing Years purchase is as follows:

$\mathrm{Yp}=(1-\mathrm{PV}) / \mathrm{I}$

Where:

$\mathrm{Yp}=$ As previously defined 


\section{PV $\quad=\quad$ Present Value $\left[1 /(1+\mathrm{I})^{\mathrm{n}} \& \mathrm{n}=\right.$ the unexpired term $]$ \\ $1=$ Yield/Capitalisation rate}

In theory, therefore, the value of a lesser leasehold term especially less than 15 years is comparatively expected to have a lower value all things being equal.

Several studies have examined the effect of tenure on property values in SSA. These include (Jacoby and Minten, 2007; Hammond and Antwi, 2010; Baffour Awuah et al., 2014a). However, these studies focus on registered title to land or ownership to land and do not examine the effect of the nature of ownership; freehold or leasehold and unexpired term of leasehold interests among others. Thus, research evidence on the impact of unexpired term of leasehold interest on real estate value in Ghana is limited. Nonetheless, Asabre (2004) and Anim-Odame et al (2009) investigated the issue but came to contrasting results. Asabre (2004) found that even though freehold estates sold at a higher price than leaseholds, unexpired leasehold term has no effect on the prices of properties. In the case of AnimOdame et al (2009), the authors found rather surprisingly that shorter-term leases are sold for higher prices than longer-term leases. As correctly pointed out by the authors, the unexpired term variable may be capturing certain systematic differences between the location of leases with shorter unexpired, which tend to be situated in older and wellestablished neighbourhoods and leases with longer unexpired terms, which are often in newer less-established neighbourhoods. Strangely, the study did not investigate this dynamic further apparently, because this issue was not the focus of the study. It is, thus, clear that the effect of unexpired leasehold terms on the values of real estate remains unclear. Further, such research evidence also appears to be rare in the developed world as perhaps the issue might have been taken for granted as settled or not fashionable. It is also important to point out that unlike the previous studies cited above that rely on transaction data, this study examines this issue from the perspective of valuers who are key players in the real estate price formation process.

Given the unambiguous theoretical predictions regarding the effect of unexpired lease terms on values of real estate, the study tests the hypotheses below: 
H1: Real estate valuers agree unanimously that the unexpired lease terms affect the value of real properties.

H2: All things being equal, differences in values placed by valuers on the same property should be unrelated to perceptions about the influence of unexpired terms of leasehold interests.

The impact of ground rent on a property value particularly in an investment valuation model is contingent upon its proportion to the periodic rental income from the property. That said, insights from the Commercial Ground Rent Lease Model profess that a lessor in a typical ground lease arrangement shifts crucial risks on the lessee (Löhr, 2017). This is because the lessee bears certain operating leverage risks in relation to the investment yield and cash flow position. Apart from development risks in converting land into full property, the lessee will also have to comply with restrictive covenants. Further, non-compliance with fundamental terms of the lease can lead to forfeiture of the property to the lessor. To compensate the lessee for the previously mentioned disadvantages and incentivise him or her to take up the lease, the lessor will have to subsidize the profitability of the lessee through a minimal ground rent (Capozza and Sick, 1991; Johnson, 2000). This will partly allow the lessee to reduce the development cost and achieve a required or higher return (Löhr, 2017).

Ground rent, therefore, conventionally tends to constitute a minimal proportion of the land or property value (Shapiro and Mackmin, 2013; Baffour Awuah et al., 2014b). For instance, ground rent in the UK has traditionally constituted around two percent of the land value (Jowsey, 2011; Shapiro and Mackmin, 2013). For peppercorn ground rent, the amount could even be very little because it is just a token amount paid to atone tenancy (Mclntosh and Sykes, 1985; the Guardian, 2017). Regarding ground rent's impact on the value of leasehold residential properties, no known study has been conducted in Ghana and SSA. Even in the developed world, not many studies have been conducted in this genre. For example, studies such as Capozza and Sick (1991), Amin and Capozza (1993) and Johnson (2000) examined the impact of ground rent. However, the core focus on these studies was on timing and intensity 
of development. Nevertheless, Capozza and Sick (1991) and Johnson (2000) found a marginal impact of ground rent on the value of leasehold residential properties. Even so, the basis of the ground rent used by Capozza and Sick (1991) is deemed unrealistic and impractical. This is because the mark-to-market ground lease payment assumes that payments adjust instantaneously to the impact of growth or change in land utilisation. Consequently, given the tiny expense nature of ground rent and the findings from the above-cited studies, it can be surmised that:

H3: All things being equal, ground rent has little or no impact on property values.

\section{Data and Methodology}

The literature discussions suggest that location specific market factors are important predictors of real estate values (Kryvobokov, 2007; Abidoye and Chan, 2016). In addition, comparable data particularly evidences of recent sales or lettings of leasehold residential properties especially those with unexpired terms of less than 15 years are vital to the impact of unexpired analysis. However, such organised data are hardly encountered in the case study country due to data paucity challenges (Obeng-Odoom and Ameyaw, 2011; Baffour Awuah et al., 2014a; 2017). There was, therefore, a need for an innovative approach to address the research issues. Given the foregoing imperatives, an extensive literature review was initially undertaken. It focused on the determination of real estate value and the factors that influence property values. The literature review dwelt on relevant real estate literature from both the developed world and SSA. In addition to the literature review, a one-day stakeholder workshop was held in Accra. The rationale for the workshop was to engage with valuation and estate surveyors, and together with the literature review identify local market specific set of real estate attributes that influence value, as well as obtain additional insights to put the study in context.

The workshop took place at the Aviation Social Centre on February 25, 2015. It was organised with the assistance of the Ghana Institution of Surveyors (GhIS), Royal Institution of 
Chartered Surveyors (RICS) and the Commonwealth Association of Surveying and Land Economy (CASLE). It was organised in three sessions comprising a presentation, breakout and plenary sessions. The presentation session focused on the background to the research and the outcome from the literature review. At the breakout session, the workshop participants were divided into groups to discuss the research issues based on preformulated questions related to the research issues. Each group had a chairperson and a rapporteur. Thus, the chairpersons supported by the rapporteurs facilitated the group discussions. The rapporteurs recorded outcomes from the discussions. The plenary session discussed the outcomes from the group discussions. The workshop, therefore, helped to confirm some of the issues identified from the literature and brought to the fore new things. It also helped to uncover data sources and identify informants useful for data collection. In particular, it complemented the literature review in identifying the relevant set of property attributes for the questionnaire survey. These attributes are set out in Table 1.

Following the workshop, a questionnaire survey of real estate valuers in Accra was undertaken. The questionnaire was divided into two parts: the first part requested professional valuers who are members of the GhIS with varied years of experience to undertake an actual valuation of a hypothetical residential property. The valuation assignment was designed to allow the opinion of values to be expressed on the same date and under the same condition. This was necessary to ensure that the opinions of value did not systematically vary due to difference in the date of valuation, the purpose or basis of valuation. Consequently, any observed difference in value opinions among the valuers is expected to be related to differences in the views of valuers on the importance of specific value attributes.

The property, a leasehold interest in a three bedroom residential property, sited on 0.093hectare land with an unexpired term of 10 years, was located in the State Housing Company Limited Neighbourhood along the Liberation Road, Airport Residential Area, Accra, a commonly known area. The area is one of the prime Government's residential areas where leases granted over properties in the $1950 \mathrm{~s}$ and 1960 s are fast expiring. The specific location, 
which is about $0.8 \mathrm{~km}$ from the Kotoka International Airport and all the other property details were given to the respondents. These comprised neighbourhood characteristics, total floor area, sketch ground floor and location plans, title and planning/building permit status and ground rent, construction details, fixtures and fittings, external works and access to services.

The second part of the questionnaire was designed to enable the respondents to rate the impact of the real estate attributes used for the study on the value of residential property. This was based on a Likert scale. Thus, a five-point Likert scale was used to elicit the extent of impact of real estate attributes on the value of residential property. The details of the Likert scale are: (1 = No impact, 2= Low impact, 3= Quite impact, 4= High impact and 5 very high impact). One hundred and ten questionnaires were administered to the respondents. The questionnaires were self-administered to the respondents and completed surveys collected by the researchers. The questionnaire administration took place between July and September 2015, and employed purposive and snow ball sampling techniques to select respondents. This was informed by the lack of reliable sample frame. The GhIS provides a yearly list of its members in good standing. However, these lists often do not provide address and location of members. Besides, there are no such lists specifically for members in Accra. This meant that probability sampling was unsuitable for use and that the employed sampling techniques were most practical and suitable techniques given the circumstances. A pre-testing of the questionnaire was carried-out prior to its administration to ensure that it passed the face and content validities test.

Relying on personal knowledge and information provided by the GhIS and some of its senior members, the respondents were contacted by e-mails and telephone to ask about their readiness to participate in the survey. Thereafter, the researchers visited and discussed the survey with the respondents, as well as administer the questionnaires. The researchers and the respondents agreed on the dates for collection of the completed questionnaires during the questionnaire administration. The GhIS informed its members of the survey and encouraged them to participate in it prior to the initial contacts. 
Proceedings from the stakeholder workshop were recorded in a notebook. These were rewritten for the purposes of clarity and analysed using insights from the thematic analysis technique. Therefore, the views of the stakeholders were read severally to track important viewpoints and common patterns. This was done through the employment of keywords and the number of times they were used. Similar themes resulting from the keywords were identified and subsequently reviewed to arrive at outcomes.

The extent of the impact of the real estate attributes on residential property values was assessed using consensus/agreement analytical framework identified by Tastle and Wierman (2007), and subsequently modified by Tastle etal. (2009). The use of the modified mean analytical framework was to allow for analysing the consensus around a given target. Details of the formulae are as follows:

$$
\operatorname{Agr}(X \mid 5)=1+\sum_{i=1}^{n} p i \log _{2}\left(1-\frac{\left|X_{i}-5\right|}{2 d_{X}}\right)
$$

Where:

Agr $=\quad$ The level of agreement on evaluation of an attribute;

$\mathrm{X}=\quad$ The scores;

$5=\quad$ The highest score;

$X_{i}=\quad$ Each score; and

$d_{X}=\quad$ The range of $\mathrm{X}\left(d_{X}=X_{\max }-X_{\text {min }}\right)$

The above formulae is devised to accommodate the ordinal nature of Likert scale scores. It ranges between zero and one with one indicating complete agreement on an issue. Conversely, zero means a complete lack of agreement. The measure in this study captures 
the extent of the respondents' agreement towards the last option on the Likert scale (five on a scale of 1-5). Thus, five the highest score on the Likert scale was used as the target score. Therefore, for example, if all the respondents consider a particular real estate attribute say age to have a very high impact by choosing five, then the consensus measure will result in one. Alternatively, if all the respondents consider it to have no impact by choosing one on the Likert scale, then the consensus measure will result in zero.

To examine whether the views expressed by the respondents influence their opinions of value, a regression analysis is carried out relating respondents' estimates of the value of the hypothetical property to two attributes of value; unexpired term and ground rent. The focus on these two variables is influenced by the fact that they are permanent features in the valuation of leasehold interests, which incidentally is the predominant estate in Ghana. An additional variable, "proximity to airport" is included in the model to serve as a control variable due to the location of the property, which is very close to an international airport. The specification of the regression is as follows:

lnvalue $=\beta_{0}+\beta_{1}$ Unexpired $+\beta_{2}$ Groundrent $+\varepsilon$

Equation 4

Where:

Invalue $=\quad$ The natural log of the value estimates,

Unexpired $=\quad$ Likert scale scores of the importance of unexpired term

Groundrent $=\quad$ Likert scale scores of the importance of ground rent

Proximity $=\quad$ Likert scale score of the importance of proximity to airport

\section{Results}


Seventy of the 110 questionnaires were returned. This represented a response rate of 63.64\%. Figures 1 and 2 display the level of experience and the nature of practice of the respondents respectively. The majority of the respondents (70\%) had less than 15 years of professional experience reflecting the exponential increase in the numbers of professional valuers over the past decade and a half. Nonetheless, there is a good representation of valuers with considerable level of experience as indicated by the $18.57 \%$ of the respondents having more than 25 years of experience. As shown in Figure 2, the respondents were drawn from diverse areas of employment with $46 \%$ engaging in private practice whereas $28 \%$ and $26 \%$ work in private and government institutions respectively.

\section{Insert figures 1 and 2 here}

Table 1 presents the results from the questionnaire survey on the perception of professional valuers regarding the factors that influence the value of properties in Accra, Ghana. The questionnaire instrument requested the respondents to indicate on a likert scale the extent to which a factor/attribute is relevant in influencing values. The responses on each attribute are summarised using the consensus measure described in the previous section. The results reveal that the attribute for which the respondents had almost unanimous consensus on its importance is the condition of the property $(\mathrm{Agr} \mid 5=0.92)$. Incidentally, as demonstrated by studies such as Sirmans et al. (2005a \& b), Zoppi et al (2015), and Abidoye and Chan (2016, 2017) most empirical studies especially in the developed world that model house prices using transaction prices in a hedonic framework do not directly include this attribute. The closest attribute that impinge on condition of a property often included in such models as found by Sirmans et al. (2005a \& b) is age of the property. However, age is not the only determinant of the condition of a property. For example, frequency of use of the property accompanied by a lack of maintenance can determine the condition. A plausible explanation for this apparent disconnect is that it may be more difficult to provide an objective indicator of the condition of a property for use in hedonic models whereas valuers have the liberty to consider subjective factors in providing an opinion of value. That said, a recent study carriedout by Abidoye and Chan (2016) in Nigeria, a SSA country incorporated the condition of a 
property in a hedonic model and identified it as one of the significant attributes that influence a house price or value. Accordingly, apart from this current finding relating to the condition of a property as a major determinant of its value corroborating similar finding from Abidoye and Chan (2016) it also reaffirms Kryvobokov (2007) observation that different attributes in different markets determine property values.

The next two attributes, which the respondents considered important in property value determination, are size of land and neighbourhood. Both attributes obtained figures close to 0.90. Unlike land size, which was identified by Sirmans et al. (2005a) as a major determinant of house price, neighbourhood seems to be a predominant attribute across most of the relevant studies as an important determinant of property values (Sirmans et al., 2005 a \& b; Kryvobokov, 2007; Zoppi et al. 2015; Abidoye and Chan, 2016, 2017).This is often subsumed in several factors, such as educational level of a population and crime level in the neighbourhood, and distance to the CDB and amenities. Title and unexpired lease term round up the top five attributes with consensus figures of 0.87 and 0.86 respectively. These two outcomes were expected since they correspond to property valuation theory and principles, in particular, the fact that valuation hinges on the subsisting interest and rights in the subject property (Blackledge, 2017; Baum et. al., 2018). At the other end of the spectrum, there was very little consensus among valuers on the significance of access to church $(\mathrm{Agr} \mid 5=0.41)$, ground rent $(\mathrm{Agr} \mid 5=0.47)$, orientation of rooms $(\mathrm{Agr} \mid 5=0.53)$, proximity to schools ( $\left.\mathrm{Agr}\right|_{5}=0.59$ ) and proximity to airport $\left(\left.\mathrm{Agr}\right|_{5}=0.62\right.$ ). The findings relating to access to church and proximity to school correspond to an earlier study by Baffour Awuah et al. (2014a). However, further analysis on unexpired terms and ground rent was carried out using regression in addition to proximity to airport, which was treated mainly as a control variable. The findings are discussed with the above findings in the subsequent sections.

\section{Insert Table 1 here}

Motivated by anecdotal evidence and results in previous studies that suggest that valuers and market players in Ghana may not be adequately taking account of factors such as 
unexpired term of leasehold interests and ground rents in pricing real properties, the study examined more closely these two factors.

The respondents were asked to estimate the market value of the leasehold interest with an unexpired term of 10 years in a hypothetical three bedroom residential property as described in the methodology section. The value estimates provided by the valuers were then used as the dependent variable in an OLS regression that treats the three factors as independent variables. The primary objective was to test whether the respondents' view on the importance of the attributes had any effect on their opinions of value. Before carrying out the regression, the views of the respondents on the three attributes were further examined to test whether they differ by nature of professional practice or levels of experience. The results, which are presented in Tables 2 and 3, show that the respondents' levels of experience and area of practice did not seem to have any influence on their views on the importance of the three attributes of value. In the case of ground rent where there appeared to be relatively larger differences in the consensus figures, a test for equality of distribution functions using Kolmogorov-Smirnov tests failed to reject the null hypothesis of no difference.

\section{Insert Tables 2 and 3 here}

The results of the OLS regression analysis are presented in Table 4. As a robustness check, as well as to provide an opportunity to examine the relationships at the conditional median and other quantiles, a quantile regression is estimated with the results presented in Table 5 . The coefficient on the control variable, proximity to airport is positive but not significant at the conventional significance level of $5 \%$ in the OLS results. The results of the quantile regression, however, show significant positive coefficient at some quantiles implying that valuers, who viewed proximity to airport as an important value attribute, placed a higher value on the property than those who did not regard this factor as important. The result can be interpreted to mean that those who view airports to have effect on values considered them to have a positive effect. 
The coefficient on ground rent is negative and significant at the $5 \%$ level for the OLS regression and at a number of quantiles in the quantile regression. This indicates that the respondents who viewed ground rent as an important factor in estimating values placed significantly lower values than those who viewed it as less important. This finding is quite surprising given that ground rent tends to be nominal and often constitute a very tiny expense item for owners of leasehold interests (Shapiro and Mackmin, 2013). In fact, in the case of the subject matter of the valuation assignment the respondents were tasked to carry out, the ground rent reserved was peppercorn and it was expected that it would not have any significant effect on the value of the property. This runs contrary to principles of the investment valuation model (Blackledge, 2017; Baum et. al., 2018). It appears the valuers who consider ground rent as important substantially overstate its impact on value. This is consistent with the well documented human tendency to overact to clues or information. For instance, Kahneman and Tversky (1973), in an experiment, show that subjects tend to put too much weight on meaningless and sometimes practically irrelevant information. There is ample empirical evidence that confirms that this behavioural pattern is prevalent (DeBondt and Thaler (1985 and 1987); Bloomfield and Hales (2002).

Tables 4 and 5 also report negative coefficient on unexpired term of leasehold interest albeit at the $10 \%$ level of significance for the OLS estimates but at $5 \%$ for the $50^{\text {th }}, 70^{\text {th }}$ and $80^{\text {th }}$ quantiles for the quantile regression estimates. This suggests that valuers who viewed unexpired term as an important factor in estimating values placed lower values on the property by taking into account the fact that the subject matter of the valuation had only 10 years unexpired term. Anecdotal evidence indicates that market participants in Ghana tend to ignore the unexpired lease terms during transactions and it appears that a good number of valuers may have been influenced by this even though valuation theory is clear on this issue. This result, taken together with the previous finding of lack of consensus indicate that valuers do not only disagree on the importance of unexpired lease terms but also that such differences in views actually affect the opinions of value. Overall, the findings suggest that the lack of consensus on the relevance of critical attributes, such as the unexpired term of 
lease and ground rent may explain the high levels of variations reported in this market (cf. Baffour Awuah and Gyamfi-Yeboah, 2017).

Insert Tables 4 and 5 here

\section{Conclusion}

This study examined the extent to which unexpired term of leasehold interests and ground rents affect the value of leasehold interests in residential properties. Anecdotal evidence and results of a number of studies indicate that the unexpired term of leasehold interests do not seem to influence the amounts paid for leasehold properties in Ghana. The effect that ground rent, which tends to constitute a minimal proportion of land or property value, has on the value of a leasehold property should theoretically be little or none. In this study, these issues are examined by analysing valuation opinions of professional real estate appraisers in Accra, Ghana.The study gives new insights based on empirical data and extend the existing literature. In particular, the study finds that the views of valuers on the relevance of unexpired term of leasehold interest affects the values placed on residential properties. This suggests that the anecdotal evidence that market participants ignore the unexpired term of leasehold interests may have split opinion on an issue that should be settled, in theory. The study also finds that the respondents who viewed ground rent as an important factor in estimating values placed significantly lower values than those who viewed it as less important. This finding is quite surprising given that ground rents tend to be nominal and often constitute a very tiny expense item for owners of leasehold interests. The results suggest that the views held by valuers do affect their value opinions. This takes on special significance when, as reported in this study, such views are inconsistent with theory or standards of professional practice as set by entities such as the International Valuation Standards. In particular, the disregard of unexpired lease terms in valuations of leasehold interests with few years remaining has serious implications for participants in the property market and in fact the stability of the market and the financial system since unjustified values arising from such valuations may be used in making purchase and lending decisions. This is especially so given the similar history of leasehold arrangements in SSA, the growing 
interest in real estate investment in Ghana and SSA, and the sophisticated nature of current investment stakeholders. It is therefore important that professional bodies and academic institutions intensify efforts to reach consensus within the valuation profession on the effects that fundamental factors such as those considered in this study have on the value of properties. Doing so will help to reduce excessive variations in value among valuers. Further, the study partly points to the increasing realisation of the significant role of ground rents in leasehold transactions especially within urban areas of SSA resonating with recommendations by studies and some experts for investment in ground rents, as well as use them as mechanism for mobilising financial resources particularly for infrastructure development in the region.

\section{References}

Abidoye, R.B.andChan, P.C.A (2016), "Critical determinants of residential property value: professionals' perspective", Journal of Facilities Management, Vol. 14 No.3, pp. 283300.

Abidoye, R.B.andChan, P.C.A (2017), “Critical review of hedonic pricing model application in property price appraisal: A case of Nigeria”, International Journal of Sustainable Development, Vol. 6, pp. 250-259.

Adegoke, J.O. (2014), “Critical factors determining rental value of residential property in Ibadan metropolis, Nigeria”, Property Management, Vol. 32 No.3, pp. 224-240.

Amin, K. and D. R. Capozza (1993), “Sequential Development”, Journal of Urban Economics, Vol. 34,pp. $142-158$.

Anim-Odame, W.K., Key, T. and Stevenson, S. (2006), "Measures of real estate values from land registration and valuation systems in emerging economies: The case of Ghana", Paper presented at $23^{\text {rd }}$ FIG Congress held in Munich, Germany, October 8-13.

Arimah B.C. (1992),“Hedonic prices and the Demand for Housing Attributes in a Third World City: The Case of Ibadan, Nigeria", Urban Studies, Vol. 29 No.5, pp. $639-651$.

Asabere, P.K. (1981), "The determinants of land values in an African city: The case of Accra, Ghana”, Land Economics, Vol. 57 No.3, pp. 385-397.

Asabere, P.K. (2004), "The pricing of the emergent leasehold (possessory) estates of Ghana”, Real Estate Economics, Vol. 32 No. 4, pp. 673-694. 
Baffour Awuah, K.G. (2013), A quantitative analysis of the economic incentives of Sub-Saharan Africa urban land use planning systems: Case study of Accra, Ghana, PhD Thesis, University of Wolverhampton, UK.

Baffour Awuah, K.G., Hammond, F.N., Lamond, J.E. and Booth, C.A. (2014a),"Benefits of land use planning in Ghana",Geoforum, Vol. 51, pp. 37-46.

Baffour Awuah, K.G., Booth, C. and Lamond, J.(2014b),“Urban land Use conversions as an avenue to increase ground rent revenue in the developing world: A suitable case for research", In 21st Annual European Real Estate Society Conference. ERES: Conference. Bucharest, Romania, 2014.

Baffour Awuah, K.G. and Gyamfi-Yeboah, F. (2017),"The role of task complexity in valuation errors analysis in a developing real estate market”, Journal of Property Research, Vol. 34 No. 1, pp. 54-76.

Barlowe, R. (1990), Land resources economics: The economics of real estate, Michigan, Prentice-Hall.

Baum, A., Mackmin, D. and Nunnington, N. (2018), The income approach to property valuation ( $7^{\text {th }}$ Edition)", London, Routledge.

Benjamin. J.D. (1995), “Controlling the incentive problems in real estate leasing”, Journal of Real Estate Finance and Economics 10, pp. 177-191.

Blackledge, M. (2017), Introducing property valuation ( $2^{\text {nd }}$ Edition), London, Routledge.

Bloomfield, R., and Hales, J. (2002), "Predicting the next step of a random walk: Experimental evidence of regime-shifting beliefs," Journal of Financial Economics 65, pp. 397-414.

Bracke, P., Pinchbeck, E.W. and Wyatt, J. (2017), "The time value of housing: Historical evidence on discount rates", Economic Journal, pp. 1-24.

Bramley, G. and Watkins, C. (1996),"The cutting edge 1996: Modeling the relationship between land use planning and new housing supply in a system of local housing markets", RICS Research Paper, pp. 930 -935.

Capozza, D. R. and G. Sick (1991),“Valuing long term leases: The option to redevelop”, Journal of Real Estate Finance and Economics, Vol.4, pp. 209 - 223.

Cheshire, P. and Sheppard, S. (2002), "The welfare economics of land use planning”, Journal of Urban Economics, Vol. 52, pp. 242-269.

Cheshire, P. and Sheppard, S. (2004), "Land markets and land market regulation: Progress towards understanding", Regional Science and Urban Economics, Vol. 34, pp. 619-637. 
Clark, E. (1988), "The rent gap and transformation of the built environment: Case studies in Malmö 1860-1985”, Human Geography, Vol. 70 B No.2, pp. 241-254.

DeBondt, W.F.M., and Thaler, R.H. (1985), "Does the stock market overreact?," Journal of Finance 40, pp. 793-805.

DeBondt, W.F.M., and Thaler, R.H. (1985), "Further evidence on investor overreaction and stock market seasonality," Journal of Finance 42, pp. 557-581.

delSaz-Salazar, S. and Garcia - Menéndez, L. (2005), "Public provision versus private provision of industrial land: A hedonic approach”, Land Use Policy, Vol. 22, pp. 215223.

Diamond Jr., D.B. (1980), "The relationship between amenities and urban land prices”, Land Economics, Vol. 56 No.1, pp. 21-32.

Dobson, S.M. and Goddard, J.A. (1992),"The determinants of commercial property prices and rent”, Bulletin of Economic Research, Vol. 44 No.4, pp. 301-321.

Emerge Capital (2014), “Freehold and leasehold title”, Insights and Research, pp. 1-4.

Fehribach, F.A., Rutherford, R.C. and Eakin, M.E. (1993), “An analysis of the determinants of industrial property valuation", Journal of Real Estate Research, Vol. 8 No.3, pp. 364376.

Fry, M.J. and Mak, J. (1984), "Is land leasing a solution to unaffordable housing? An Answer from fee simple versus leasehold property price differentials in Hawaii", Economic Inquiry, Vol. 22 No. 4, pp. 529-549.

Glaeser, E.L. and Ward, B.A. (2009),"The causes and consequences of land use regulation: Evidence from Greater Boston”, Journal of Urban Economics, Vol. 6 No.5, pp. 265 278.

Giglio, S., Maggiori, M. and Stroebel, J. (2014), "Very long-run discount rates", Quarterly Journal of Economics 130 No.1, pp1-53.

Griffiths, A. and Walls, S. (2011), Economics for business and management ( $3^{\text {rd } E d n .), ~ E s s e x, ~}$ Pearson Education Ltd.

Hammond, F.N. and Antwi, Y. A. (2010), Economic analysis of Sub-Saharan Africa real estate policies, London, Palgrave Macmillan.

Hicks, J.F. (1972), “The contractual nature of real property leases”, Baylor Law Review 24, pp. 443-554. 
Home, R. (2012), Towards a pro-poor land law in sub-Saharan Africa. In: Homes, R. (Ed.) Essays in African land law, Pretoria, Pretoria University Law Press.

Hong, Y.H. (1995), Public land leasing in Hong Kong: Flexibility and rigidity in allocation the surplus value, PhD Thesis, Massachusetts Institute of Technology.

Ihlanfeldt, K.R. (2007), "The Effect of Land Use Regulation on Housing and Land Prices”, Journal of Urban Economics, Vol. 61 No.3, pp. $420-435$.

Ihlanfeldt, K.R. (2009),“Does Comprehensive Land Use Planning Improve Cities? Land Economics, Vol. 85, pp. 74-86.

Jacoby, H.G. and Minten, B. (2007), "Is land titling in in Sub-Saharan Africa cost-effective? Evidence from Madagascar”, The World Bank Economic Review, Vol.21, Issue 3, pp $461-485$.

Johnson, D.D. (2000), “Long-term ground leases, the redevelopment option and contract incentives", Real Estate Economics, Vol. 29, No. 3, pp. 451-484.

Jowsey, E. (2011), Real Estate Economics, London, Palgrave Macmillan.

Kahneman, D. and Tversky, A. (1973), “On the psychology of prediction” Psychological Review, 80, pp. 237-251.

Kryvobokov, M. (2007),"What location attributes are the most important for market value? Extraction of attributes from regression models”, Property Management, Vol. 25 No.3, pp. 257-286.

Lipscomb, J.B. and Gray, J.B. (1995),“A connection between paired data analysis and regression analysis estimating sales adjustments", Journal of Real Estate Research, Vol. 10 No.2, pp. 175-183.

Lockwood, L.J. and Rutherford, R.C. (1996), “Determinants of industrial property value, Real Estate Economics, Vol. 24 No.2, pp. 257-272.

Löhr, D. (2017), “Sustainable housing: A ground lease partnership model”, Land Use Policy, Vol. 60, pp. 281-286.

Marshall, A. (1961), Principles of economics (9th variorum Edn.), London, Macmillan.

McIntosh, A.P.J. and Sykes, S.G. (1985),“Leasehold Investments and Other Rent Sharing Arrangements", A Guide to Institutional Property Investment, pp. 91-108.

Medda, F. (2012), “Land value capture finance for transport accessibility: A review”, Journal of Transport Geography, Vol.25, pp.154-161. 
Megbolugbe, I.F. (1989),"A hedonic index model: The housing market of Jos, Nigeria”, Urban Studies, Vol. 26 No. 5, pp. 486-494.

McDonald, J.F. and McMillen, D.P. (2011), Urban economics and real estate: Theory and policy ( $2^{\text {nd }}$ Edn.), Hoboken, John Wiley and Sons.

Miller, M.H and Upton, C.W. (1976), "Leasing, buying, and the cost of capital services", Journal of Finance, Vol. 31 No. 3, pp. 761-786.

Obeng-Odoom, F. and Ameyaw, S. (2011),"The state of surveying profession in Africa: A Ghanaian perspective", Property Management, Vol. 29 No.3, pp. 262-284.

Okoth-Ogendo, H.W.O. (2000), Legislative approaches to customary tenure and tenure reform in East Africa. In: Toulmin, C., Quan, J.F. (Eds.) Evolving land rights, policy and tenure in Africa, London, DFID/IIED/INR.

Orefice, M.(2007), Estimo Civile [Handbook of Civil Real Estate Economics], vol. 2.UTET Università, Turin, Italy.

O'Sullivan, S. and Sheffrin, M. (2007), Economics Principles (California Edn.), California: Prentice Hall.

Owusu Ansah, A. (2012),"Examination of the determinants of housing values in urban Ghana and implications for policy makers", Journal of African Real Estate Research, Vol. 2 No. 1, pp. 58-85.

Palmquist, R.B.(1984), "Estimating the demand for the characteristic of housing", Rev. Econ. Stat. Vol. 66 No.3, pp. 394-404.

Shapiro, E., Davies, K. and Mackmin, D. (2013), Modern methods of valuation (11 ${ }^{\text {th }}$ Edn.), London, Estates Gazette.

Sirmans, G.S., McDonald, L., Macpherson, D.A. and Zietz, E.N. (2005a),“The composition of hedonic pricing models”, Journal of Real Estate Literature, Vol. 13 No.1, pp. 3-43.

Sirmans, G.S., Macpherson, D.A. and Zietz, E.N. (2005b),"The value of housing characteristics: A meta-analysis. National Association of Realtors, USA”, Paper presented at the Mid-Year Meeting of the American Real Estate and Urban Economics Association May 2005.

Sloman, J., Wride, A. and Garrat, D. (2012), Economics ( $8^{\text {th }}$ Edn.), London, Prentice Hall.

The Guardian (2017) [UK Edition],“Leasehold houses and the ground rent scandal: all you need to know”, 25 July, 2017:16.05 BST. 
Tastle, W.J. and Wierman, M.J. (2007),"Consensus and dissention: A measure of ordinal dispersion”, International Journal of Approximate Reasoning, Vol. 45, pp. 531-545.

Tastle, W.J., Boasson, E. and Wierman, M.J. (2009),“Assessing team performance in information systems projects”, Information System Educational Journal, Vol. 7 No.90, pp. 1545-679X.

Viruly, F., \& Hopkins, N. (2014), Unleashing Sub-Saharan Africa property markets, London, RICS.

Watkins, C. (1999), "Property valuation and the structure of urban housing market”, Journal of Property Investment and Finance, Vol. 17 No.2, pp. 157-175.

Zoppi, C., Argiolasi, M. and Lai, S. (2015), "Factors influencing the value of houses: Estimates for the city of Cagliari, Italy", Land Use Policy, Vol. 40, pp. 367-380. 